\title{
Milk Fatty Acid Composition of Grazing Dairy Cows When Supplemented with Linseed Oil
}

\author{
G. Flowers, ${ }^{*}$ S. A. Ibrahim, $\dagger$ and A. A. AbuGhazaleh ${ }^{\star 1}$ \\ *Department of Animal Science, Food and Nutrition, Southern Illinois University, Carbondale 62901 \\ †Department of Family and Consumer Sciences, North Carolina A\&T State University, Greensboro 27411
}

\begin{abstract}
The effects of varying amounts of linseed oil (LSO) in grazing dairy cows' diet on milk conjugated linoleic acid (cis-9, trans-11 CLA) were investigated in this study. Twelve Holstein cows in midlactation (150 \pm 19 DIM) were placed on alfalfa-based pasture and assigned to 4 treatments using a $4 \times 4$ Latin square design with 3 -wk periods. Treatments were: 1 ) control grain supplement; 2) control grain supplement containing $170 \mathrm{~g}$ of LSO (LSO1); 3) control grain supplement containing $340 \mathrm{~g}$ of LSO (LSO2); and 4) control grain supplement containing $510 \mathrm{~g}$ of LSO (LSO3). Grain supplements were offered at $7 \mathrm{~kg} / \mathrm{d}$. Additional $100 \mathrm{~g} / \mathrm{d}$ of algae, divided evenly between the 2 feeding times, were added to every treatment diet. Milk samples were collected during the last $3 \mathrm{~d}$ of each period and analyzed for chemical and fatty acid composition. Treatments had no effect on milk production $(18.9,18.5,19.6$, and 19.1 $\mathrm{kg} / \mathrm{d}$ for treatments 1 to 4 , respectively). Linseed oil supplementation caused a quadratic increase in milk fat $(3.23,3.44,3.35$, and $3.27 \%$ for treatments 1 to 4 , respectively) and protein $(3.03,3.19,3.12$, and $3.08 \%)$ contents. Concentrations ( $\mathrm{g} / 100 \mathrm{~g}$ of fatty acids) of milk cis-9, trans-11 CLA $(1.12,1.18,1.39$, and 1.65 for treatments 1 to 4 , respectively) and VA (3.39, 3.62, 4.25, and 4.89) linearly increased with LSO supplementations. Results from this trial suggest that the increase in milk cis-9, trans-11 CLA was proportional to the amounts of LSO fed. In conclusion, adding LSO to grazing dairy cow diets can improve the nutritional value of milk without compromising milk composition or cow performance.
\end{abstract}

Key words: conjugated linoleic acid, dairy cow, linseed oil, milk fatty acid composition

\section{INTRODUCTION}

Conjugated linoleic acid (CLA) isomers are potentially valuable fatty acids chiefly found in the milk of

Received June 2, 2007.

Accepted November 1, 2007.

${ }^{1}$ Corresponding author: aabugha@siu.edu ruminants. The most common of these isomers, cis9, trans-11, has been found to have anticarcinogenic properties and possibly other positive effects for human health (Bhattacharya et al., 2006).

The $c i s-9$, trans-11 CLA is synthesized as an intermediate product in the rumen during the biohydrogenation of dietary linoleic acid or in animal tissues by $\Delta^{9}$-desaturase from vaccenic acid (VA, trans-11 C18:1), another intermediate in ruminal biohydrogenation (Griinari and Bauman, 1999). Unlike linoleic acid, biohydrogenation of linolenic acid (C18:3n-3) in the rumen leads to the formation of VA, not cis-9, trans-11 CLA (Harfoot and Hazlewood, 1997). Approximately $80 \%$ of cis-9, trans-11 CLA appearing in milk fat is synthesized in the mammary gland via $\Delta^{9}$-desaturase (Mosley et al., 2006).

Because of their potential health benefits, there is considerable interest in increasing CLA concentration levels in milk fat. Efforts to do this have involved modifying, supplementing, or both, the diets of dairy cows. Studies reporting supplementing dairy cows' diet with plant oils (Dhiman et al., 2000; Rego et al., 2005b; Bu et al., 2007), marine oil (Donovan et al., 2000; Rego et al., 2005a), or algae (Franklin et al., 1999) have all resulted in substantial increases in milk cis-9, trans11 CLA content. AbuGhazaleh et al. $(2002,2003)$ and Whitlock et al. (2002) demonstrated that the greatest concentrations of cis-9, trans-11 CLA in milk fat can be obtained by adding fish oil along with plant oils high in linoleic acid (sunflower oil) or linolenic acid (linseed oil) to dairy cow diets. AbuGhazaleh and Jenkins (2004b) showed that the stimulatory effect of dietary fish oil and algae on milk cis-9, trans-11 CLA production is due to the inhibitory effect of docosahexaenoic acid (C22:6; DHA) on the ruminal reduction of VA to stearic acid. However, including fish oil in dairy cow diets can cause a reduction in feed intake and milk fat content (Donovan et al., 2000; Whitlock et al., 2002; Rego et al., 2005a).

Moreover, despite evidence that it can lead to higher CLA content, the effect of dietary oil level on milk CLA content has not been consistent. Milk CLA levels significantly increased when linseed oil (LSO) was fed to 
dairy cows at $460 \mathrm{~g} / \mathrm{d}$ but did not additionally increase when LSO intake was increased to $880 \mathrm{~g} / \mathrm{d}$ (Dhiman et al., 2000). Additionally, Rego et al. (2005a) reported similar increases in milk CLA when fish oil was added to grazing dairy cow diets at 160 and $320 \mathrm{~g} / \mathrm{d}$. When soybean oil was included in dairy cow diets at 0 (control), $0.5,1,2$, and $4 \%$ of diet DM, the CLA content of milk significantly increased only when soybean oil was added at 2 and $4 \%$ of diet DM when compared with the control (Dhiman et al., 2000).

Another factor of interest here is the combination of feeding regimen and diet oil supplementation. Although the effect of plant oils on milk cis-9, trans-11 CLA is well documented under confinement feeding system, there is less information in the literature concerning the effect of oil supplementation levels on milk cis-9, trans-11 CLA content of grazing dairy cows. Studies have shown that milk CLA levels are typically higher in cows fed pasture-based diets than TMR (Loor et al., 2003; Schroeder et al., 2003; Bargo et al., 2006). To improve our understanding of the effects of plant oil supplementation on CLA content on pasture grazing dairy cows, this trial was conducted to determine the effects of varying amounts of LSO in grazing dairy cow diets on milk cis-9, trans-11 CLA.

\section{MATERIALS AND METHODS}

All procedures for this trial were approved by the Southern Illinois University Intuitional Animal Care and Use Committee. Cows were selected from the Southern Illinois University Carbondale Dairy Research Center. The experiment was conducted between April and July 2006. Twelve multiparous Holstein cows at $150 \pm 19 \mathrm{DIM}$ and averaging $31.5 \pm 3.7 \mathrm{~kg} / \mathrm{d}$ of milk yield were used in a $4 \times 4$ Latin square design with 3 wk periods. The first $18 \mathrm{~d}$ were for diet acclimatization, and the last $3 \mathrm{~d}$ were for sampling. Cows within a square were randomly assigned to dietary treatments. All cows were grazed together on alfalfa-fescue-clover-weeds mixed pasture (50:20:20:10 wt/wt) during the entire experiment and fed grain supplements. An 8-ha pasture subdivided into ten 0.8 -ha paddocks, yielding approximately $270 \mathrm{~m}^{2}$ of pasture area per cow per day, was used. Cows were rotated throughout the 10 paddocks to promote continuous grazing. Water was available to cows at all times.

Treatments were 1) control grain supplement, 2) control grain supplement with $170 \mathrm{~g} / \mathrm{d}$ of LSO (LSO1), 3) control grain supplement with $340 \mathrm{~g} / \mathrm{d}$ of LSO (LSO2), and 4) control grain supplement with $510 \mathrm{~g} / \mathrm{d}$ of LSO (LSO3). The grain supplement contained corn, dried molasses, soybean meal, meat and bone meal, minerals, and vitamins (Table 1). Grain supplements $(7 \mathrm{~kg} / \mathrm{d}$ ) were offered in 2 equal portions after the morning and afternoon milking in the barn using Calan Broadbent feeder doors (American Calan Inc., Northwood, NH) for individual feed intakes. Fifty grams of S-type gold algae (source of DHA; Martek Inc., Baltimore, MD) was added as a top dress to each grain feeding. The algae were stored at $5^{\circ} \mathrm{C}$ until use. Amounts of grain supplement offered, and orts were recorded daily for each cow.

The cows were milked daily at 0630 and $1730 \mathrm{~h}$ and milk yield was recorded at each milking. Milk samples from both the morning and evening milkings were collected during the last $3 \mathrm{~d}$ of each period. Twenty-four hour composites of each cow's milk, amounts proportional to milk yield at each time, were divided into 2 portions for analysis. One portion was stored at $5^{\circ} \mathrm{C}$ and sent to a laboratory (Prairie Farms, Carterville, IL) to be analyzed for fat, true protein, and lactose (AOAC, 2000; method 972.16) by midinfrared spectrophotometry (Foss 303 Milk-O-Scan; Foss Foods Inc.; Prairie Farms, Carlinville, IL) and SCC (Fossomatic 6000; Foss Incorporated, Eden Prairie, MN; AOAC, 2000 , method 975.16). The other portion of each sample was stored at $-20^{\circ} \mathrm{C}$ for fatty acid analysis.

Pasture, grain supplement, and algae samples were taken during wk 2 and 3 of the each period and stored at $-20^{\circ} \mathrm{C}$ until analysis for chemical and fatty acid composition. Pasture samples were taken randomly from 5 different locations per paddocks using a $0.50-\mathrm{m}^{2}$ quadrant. The plants were clipped to a $2.5-\mathrm{cm}$ stubble height using metal shears. Pasture samples were composited per period and stored at $-20^{\circ} \mathrm{C}$ until analysis for chemical and fatty acid composition.

Pasture and grain supplement samples were freezedried (Labconco Freeze Dry System, Labconco, Kansas City, MO) and then ground through a standard model No. 3 Wiley mill (Arthur H. Thomas Co., Philadelphia, PA) with a 2-mm screen. Samples were analyzed for CP (method 976.05), and ash (method 942.05) according to AOAC methods (2000). Samples were reground (Brinkman ultracentrifuge mill) through a 1-mm screen prior to analyses for fatty acids (Kramer et al., 1997) and fiber. The NDF was determined using the Van Soest et al. (1991) procedure. The heat stable amylase and sodium sulphite were used to determine NDF. Acid detergent fiber was determined using cetyl trimethyl ammonium bromide and $1 \mathrm{~N} \mathrm{H}_{2} \mathrm{SO}_{4}$ as described by Robertson and Van Soest (1981). The NDF and ADF are expressed including the residual ash. Body weights and BCS were recorded at the end of each period.

Milk samples were thawed in a $35^{\circ} \mathrm{C}$ water bath and 1 -mL was transferred into a glass test tube $(16 \times 200$ $\mathrm{mm}$ ) with Teflon-lined screw caps, stored at $-80^{\circ} \mathrm{C}$ for 6 $h$, freeze-dried, and then methylated using the $\mathrm{NaOCH}_{3}$ 
FLOWERS ET AL.

Table 1. Ingredient and chemical composition of treatments and pasture

\begin{tabular}{|c|c|c|c|c|c|}
\hline \multirow[b]{2}{*}{ Item $(\%$ of $\mathrm{DM})$} & \multicolumn{4}{|c|}{ Treatment ${ }^{1}$} & \multirow[b]{2}{*}{ Pasture } \\
\hline & Control & LSO1 & LSO2 & LSO3 & \\
\hline Cracked corn & 49.00 & 48.10 & 45.00 & 42.00 & \\
\hline Linseed oil & 0.00 & 2.57 & 5.12 & 7.67 & \\
\hline Dried molasses & 10.40 & 10.40 & 10.40 & 10.40 & \\
\hline Soybean meal, $48 \%$ CP & 29.40 & 27.80 & 28.20 & 28.80 & \\
\hline Meat and bone meal & 4.18 & 4.16 & 4.16 & 4.14 & \\
\hline Limestone & 3.48 & 3.47 & 3.46 & 3.45 & \\
\hline Dicalcium phosphate & 1.74 & 1.74 & 1.73 & 1.73 & \\
\hline Magnesium oxide & 0.35 & 0.35 & 0.35 & 0.35 & \\
\hline $\mathrm{Zn}$ trace mineralized salt & 0.69 & 0.69 & 0.69 & 0.69 & \\
\hline Vitamin E premix ${ }^{2}$ & 0.35 & 0.35 & 0.35 & 0.35 & \\
\hline Vitamin ADE premix ${ }^{3}$ & 0.35 & 0.35 & 0.35 & 0.35 & \\
\hline \multicolumn{6}{|l|}{ Composition, \% of DM } \\
\hline Ash & $10.2 \pm 1.07$ & $9.45 \pm 0.73$ & $8.85 \pm 0.86$ & $9.11 \pm 0.67$ & $8.04 \pm 2.03$ \\
\hline $\mathrm{CP}$ & $23.2 \pm 1.81$ & $21.0 \pm 1.25$ & $20.8 \pm 1.33$ & $21.4 \pm 1.27$ & $11.3 \pm 1.26$ \\
\hline NDF & $23.7 \pm 0.49$ & $23.7 \pm 0.47$ & $24.7 \pm 0.62$ & $25.9 \pm 0.46$ & $64.1 \pm 7.96$ \\
\hline $\mathrm{ADF}$ & $13.2 \pm 0.69$ & $11.9 \pm 0.88$ & $11.9 \pm 0.38$ & $11.7 \pm 0.80$ & $37.3 \pm 5.76$ \\
\hline $\mathrm{NFC}^{4}$ & 51.90 & 50.76 & 48.68 & 46.52 & \\
\hline $\mathrm{NE}_{\mathrm{L}},{ }^{5} \mathrm{Mcal} / \mathrm{kg}$ & 1.76 & 1.85 & 1.95 & 2.05 & \\
\hline
\end{tabular}

${ }^{1}$ Control = control with no linseed oil; LSO1 = control with $170 \mathrm{~g} / \mathrm{d}$ of linseed oil; LSO2 = control with $340 \mathrm{~g} / \mathrm{d}$ of linseed oil; LSO3 = control with $510 \mathrm{~g} / \mathrm{d}$ of linseed oil.

${ }^{2}$ Contained 44,000 IU of vitamin E/kg.

${ }^{3}$ Contained 4,400,000 IU of vitamin A, 880,000 IU of vitamin D, and $400 \mathrm{IU}$ of vitamin $\mathrm{E} / \mathrm{kg}$.

${ }^{4}$ Estimated NRC (2001).

${ }^{5}$ Estimated NRC (2001).

and $\mathrm{HCl}$ 2-step procedure as outlined by Kramer et al. (1997). Methylated fatty acids were then analyzed for fatty acids using a Shimadzu GC-2010 gas chromatograph (Shimadzu Scientific Instruments Inc., Columbia, MD) equipped with a flame ionization detector and a Supelco 100-m SP-2560 fused silica capillary column (0.25 mm i.d. $\times 0.2 \mu \mathrm{m}$ film thickness). The helium carrier gas was maintained at a linear velocity of 23 $\mathrm{cm} / \mathrm{s}$. The oven temperature was programmed for $135^{\circ} \mathrm{C}$ for $5 \mathrm{~min}$, then increased at $5^{\circ} \mathrm{C} / \mathrm{min}$ to $165^{\circ} \mathrm{C}$, held there for $80 \mathrm{~min}$, then increased at $1.5^{\circ} \mathrm{C} / \mathrm{min}$ to $180^{\circ} \mathrm{C}$, then increased at $5^{\circ} \mathrm{C} / \mathrm{min}$ to $245^{\circ} \mathrm{C}$ and held there for $9 \mathrm{~min}$. The injector and detector temperatures were set at $255^{\circ} \mathrm{C}$. Peaks were identified by comparing the retention times with those of corresponding standards (Nu-Chek Prep., Elysian, MN; Supelco, Bellefonte, PA; and Larodan Fine Chemicals, Malmo, Sweden). The trans C18:1 isomers that were not available commercially (trans-6/8, trans-10, trans-12, trans-16) were identified according to the elution sequence reported by Loor et al. (2005). Heptadecanoic acid (C17:0) was added to all feed samples as an internal standard.

Data for fatty acid composition, grain supplement intake, milk production and composition, body weight, and body condition scores are reported as least squares means. Data were analyzed as a Latin square using the PROC MIXED of SAS (SAS Institute Inc., Cary, NC). The statistical model includes cow, period, sample, diet, and residual error. Fixed effects were period and diet, whereas cow was the random effect. Preplanned comparisons were linear, quadratic, and LSO vs. control. Significance was declared at $P<0.05$.

\section{RESULTS}

The nutrient content and fatty acid composition of grain supplements and pasture are presented in Tables 1 and 2. The average $\mathrm{CP}, \mathrm{ADF}, \mathrm{NDF}$, and ash content (DM basis) for pasture were 11.3, 37.3, 64.3, and 8.04\%, respectively. Pasture fatty acids content averaged 15.0 $\mathrm{mg} / \mathrm{g}$ of DM. As expected, fatty acid content in grain supplements increased as amounts of LSO increased averaging 18.4, 34.7, 53.2, and $72.1 \mathrm{mg} / \mathrm{g}$ of $\mathrm{DM}$ for treatments 1 to 4 , respectively. Linolenic acid was the major fatty acid in the pasture grasses accounting for approximately $40.8 \%$ of total fatty acids (Table 2 ). The second major fatty acid in the pasture was linoleic acid accounting for $13.7 \%$ of total fatty acids. Addition of LSO increased the concentrations ( $\mathrm{mg} / \mathrm{g}$ of DM) of oleic, linoleic, and linolenic acids in grain supplements (Table 2). Concentrations ( $\mathrm{mg} / \mathrm{g}$ of grain $\mathrm{DM}$ ) of linolenic acid $(0.69,8.2,17.6$, and 28.2 with treatments 1 to 4 , respectively), linoleic acid (5.8, 11.7, 15.0, and 18.1) and oleic acid $(4.7,7.7,11.1$, and 14.8) increased as the amounts of LSO in grain supplements increased. The major fatty acid in algae was DHA accounting for $38.3 \%$ of the total fatty acids. 
MILK CONJUGATED LINOLEIC ACID WITH LINSEED OIL

Table 2. Fatty acid composition for treatments, pasture, algae, and linseed oil

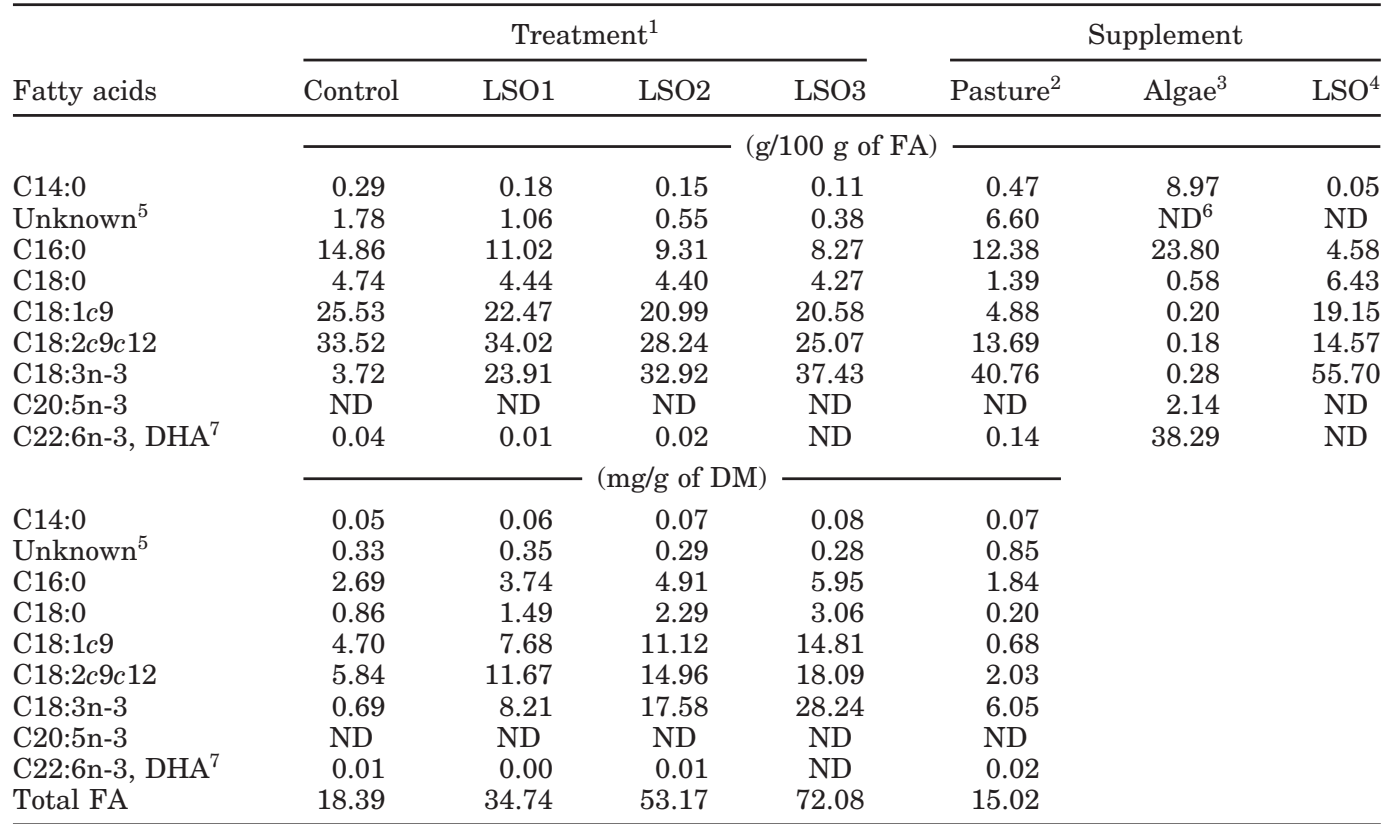

\footnotetext{
${ }^{1}$ Control $=$ control with no linseed oil; LSO1 = control with $170 \mathrm{~g} / \mathrm{d}$ of linseed oil; LSO2 = control with $340 \mathrm{~g} / \mathrm{d}$ of linseed oil; LSO3 = control with $510 \mathrm{~g} / \mathrm{d}$ of linseed oil.

${ }^{2}$ Pasture = alfalfa-fescue-clover-weeds (50:20:20:10 wt/wt).

${ }^{3} \mathrm{~S}$ type Gold algae (Martek Inc., Baltimore, MD).

${ }^{4} \mathrm{LSO}=$ linseed oil.

${ }^{5}$ Unknown = unknown peak between C14:0 and C16:0.

${ }^{6} \mathrm{ND}=$ not detected or detected at $<0.01$.

${ }^{7} \mathrm{DHA}=$ docosahexaenoic acid.
}

The effect of treatments on milk yield and composition is presented in Table 3 . There was no effect $(P=$ $0.87)$ of treatments on milk yield $(18.9,18.5,19.6$, and $19.1 \mathrm{~kg} / \mathrm{d}$ for treatments 1 to 4 , respectively). Linseed oil supplementation resulted in a quadratic increase $(P$ $<0.02$ ) in milk fat and protein contents. However, when LSO diets were contrasted against the control treatment diet, milk fat percentages and yield were similar $(P>0.10)$. Milk fat percentages averaged $3.23,3.44$, 3.35 , and 3.27 for treatments 1 to 4 , respectively. Milk protein percentages $(3.03,3.19,3.12$, and 3.08 for treatments 1 to 4 , respectively) and total solids $(11.70,12.07$, 11.90 , and 11.90) were higher $(P<0.05)$ with LSO diets compared with control treatment. Treatments had no effect $(P>0.10)$ on grain supplement intake, SCC, BW, and BCS (Table 3).

The effects of treatments on milk fatty acid composition are presented in Table 4. Compared with the control treatment, the concentrations of the even chained C6:0 to C16:0 were lower $(P<0.05)$ with the LSO treatments (Table 4). Similarly, yields of even-chained C6:0 to C16:0 isomers were lower $(P<0.05)$ with the LSO treatments compared with the control treatment (data not shown). As the amounts of LSO in grain supple- ments increased, the concentrations of even-chained C4:0 to C16:0 decreased in a linear manner $(P<0.001)$. The concentrations of even-chained C4:0 to C16:0 averaged $39.3,38.8,36.8$, and $33.7 \mathrm{~g} / 100 \mathrm{~g}$ of total fatty acids for treatments 1 to 4 , respectively. Addition of LSO to grain supplements linearly decreased $(P<$ $0.001)$ the concentrations of milk C11:0, C15:0, and C17:0 compared with the control treatment. Treatments had no effect on milk C18:0 concentrations or yields (data not shown).

Milk trans C18:1 concentrations were higher $(P<$ 0.001 ) with the LSO treatments compared with the control treatment diet. Concentrations of milk trans C18:1 linearly increased $(P<0.001)$ by 9,32 , and $52 \%$ with the LSO1, LSO2, and LSO3 treatments, respectively, compared with the control treatment diet. Vaccenic acid was the major trans $\mathrm{C} 18: 1$ isomer in all treatments, accounting for approximately 53\% (ranged from 52 to $54 \%$ ) of total trans C18:1 isomers. The addition of LSO to the grain supplements increased $(P<0.001)$ milk VA concentrations when compared with the control treatment. Increasing the amount of LSO in grain supplements caused in a linear increase $(P<0.001)$ in milk VA $(3.39,3.62,4.25$, and $4.89 \mathrm{~g} / 100 \mathrm{~g}$ of fatty acids 
FLOWERS ET AL.

Table 3. Effect of treatments on milk yield, milk composition, BW, and BCS

\begin{tabular}{|c|c|c|c|c|c|c|c|c|c|}
\hline \multirow[b]{2}{*}{ Item } & \multicolumn{4}{|c|}{ Treatment $^{1}$} & \multirow[b]{2}{*}{ SEM } & \multicolumn{4}{|c|}{ Contrast $^{2}$} \\
\hline & Control & LSO1 & $\mathrm{LSO} 2$ & LSO3 & & Lin & Quad & Contro & ol vs. LSO \\
\hline & & & & & & & $-P$ & value & \\
\hline Milk, kg/d & 18.93 & 18.50 & 19.60 & 19.10 & 1.26 & 0.63 & 0.94 & & 0.87 \\
\hline \multicolumn{10}{|l|}{ Fat } \\
\hline$\%$ & 3.23 & 3.44 & 3.35 & 3.27 & 0.08 & 0.71 & 0.02 & & 0.10 \\
\hline $\mathrm{kg} / \mathrm{d}$ & 0.60 & 0.64 & 0.66 & 0.63 & 0.04 & 0.42 & 0.12 & & 0.18 \\
\hline \multicolumn{10}{|l|}{ Protein } \\
\hline$\%$ & 3.03 & 3.19 & 3.12 & 3.08 & 0.05 & 0.60 & 0.02 & & 0.05 \\
\hline $\mathrm{kg} / \mathrm{d}$ & 0.59 & 0.59 & 0.58 & 0.56 & 0.07 & 0.32 & 0.82 & & 0.50 \\
\hline \multicolumn{10}{|l|}{ Lactose } \\
\hline$\%$ & 4.56 & 4.40 & 4.59 & 4.66 & 0.09 & 0.14 & 0.11 & & 0.89 \\
\hline $\mathrm{kg} / \mathrm{d}$ & 1.90 & 1.88 & 1.98 & 2.02 & 0.12 & 0.10 & 0.53 & & 0.47 \\
\hline \multicolumn{10}{|l|}{ Total solids } \\
\hline$\%$ & 11.70 & 12.07 & 11.90 & 11.90 & 0.12 & 0.08 & 0.04 & & 0.05 \\
\hline $\mathrm{kg} / \mathrm{d}$ & 2.99 & 2.94 & 3.12 & 3.61 & 0.45 & $<0.01$ & 0.10 & & 0.23 \\
\hline MUN, \% & 16.70 & 17.0 & 15.40 & 16.20 & 0.54 & 0.12 & 0.54 & & 0.35 \\
\hline $\mathrm{SCC} \times 10^{3} / \mathrm{mL}$ & 272 & 275 & 367 & 410 & 80.30 & 0.15 & 0.79 & & 0.39 \\
\hline $\mathrm{BW}, \mathrm{kg}$ & 631 & 599 & 600 & 604 & 29.23 & 0.16 & 0.82 & & 0.23 \\
\hline $\mathrm{BCS}^{3}$ & 2.83 & 2.63 & 2.71 & 2.74 & 0.12 & 0.49 & 0.12 & & 0.09 \\
\hline Grain supplement intake, kg/d & 6.92 & 6.94 & 6.90 & 6.96 & 0.10 & 0.90 & 0.89 & & 0.93 \\
\hline
\end{tabular}

${ }^{1}$ Control = control with no linseed oil; LSO1 = control with $170 \mathrm{~g} / \mathrm{d}$ of linseed oil; LSO2 = control with $340 \mathrm{~g} / \mathrm{d}$ of linseed oil; LSO3 = control with $510 \mathrm{~g} / \mathrm{d}$ of linseed oil.

${ }^{2} \mathrm{Lin}=$ linear effect, $\mathrm{Quad}=$ quadratic effect, and control vs. LSO = control versus linseed oil supplementation.

${ }^{3}$ Scored on a 5 -point scale where $1=$ emaciated to $5=$ overly fat.

for treatments 1 to 4 , respectively) and trans-10 C18:1 $(0.56,0.59,0.72$, and $0.82 \mathrm{~g} / 100 \mathrm{~g}$ of fatty acids for treatments 1 to 4 , respectively) concentrations. The addition of LSO to grain supplements also linearly increased $(P<0.001)$ the concentrations of milk trans-6/ $8,9,12$, and 16 when compared with the control treatment.

Linseed oil supplementation increased concentrations $(P<0.001)$ of milk cis-9, trans-11 CLA when compared with the control treatment (Table 4). As the amount of LSO in the grain supplements increased, milk cis-9, trans-11 CLA concentrations (1.12, 1.18, 1.39 , and $1.65 \mathrm{~g} / 100 \mathrm{~g}$ of fatty acids for treatments 1 to 4 , respectively) and yields (5.45, 5.73, 6.79, and $7.99 \mathrm{~g} /$ d) increased in a linear manner $(P<0.001)$. Milk trans, trans CLA concentrations increased by $36.4,54.5$, and $72.7 \%$ with the LSO1, LSO2, and LSO3 treatments, respectively, relative to the control treatment (Table 4).

Linseed oil supplementation also affected milk n-3 fatty acids concentrations (Table 4 ). Milk n-3 fatty acids concentrations $(0.86,1.09,1.26$, and $1.25 \mathrm{~g} / 100 \mathrm{~g}$ of fatty acids for treatments 1 to 4 , respectively) and yields $(4.16,5.29,6.11$, and $6.05 \mathrm{~g} / \mathrm{d})$ linearly increased $(P<$ 0.001 ) as the level of LSO in grain supplements increased. Milk linolenic acid content increased by 32.2, 71.2 , and $74.5 \%$ with the LSO1, LSO2, and LSO3 treatments, respectively, compared with the control treatment. Treatments had no effect $(P>0.008)$ on milk
DHA content $(0.14,0.19,0.12$, and $0.11 \mathrm{~g} / 100 \mathrm{~g}$ of fatty acids for treatments 1 to 4 , respectively).

\section{DISCUSSION}

Supplementing grazing dairy cow diets with different amounts of LSO had no effect on milk yield and grain intake. Others (Schroeder et al., 2003; Rego et al., 2005b; Boken et al., 2005; Shingfield et al., 2005) have also reported similar effects when cow diets were supplemented with plant oils. Supplementing dairy cow diets with high amounts of plant oils often cause a drop in feed intake and therefore milk yield (Chilliard et al., 2001; Rego et al., 2005b) possibly as a result of their negative affects on feed digestibility and rumen fermentation (Jenkins, 1994). In the present study, all cows consumed equal amounts of grain supplements, which may explain the similar milk yield among treatments.

Effect of dietary plant oil supplementation on milk fat content has not been consistent. Bu et al. (2007) and AbuGhazaleh and Holmes (2007) reported no effect of dietary oil supplementations on milk fat content. In contrast, others (AbuGhazaleh et al., 2002; Rego et al., 2005b; Shingfield et al., 2006) reported marked reduction in milk fat content with dietary oil supplementations. Bauman and Griinari (2003) have suggested that milk fat depression (MFD) was related to the direct action on the mammary gland of specific fatty acid iso- 
Table 4. Effect of treatments on milk fatty acid composition

\begin{tabular}{|c|c|c|c|c|c|c|c|c|}
\hline \multirow[b]{2}{*}{ Item } & \multicolumn{4}{|c|}{ Treatment $^{1}$} & \multirow[b]{2}{*}{ SEM } & \multicolumn{3}{|c|}{ Contrast $^{2}$} \\
\hline & Control & LSO1 & $\mathrm{LSO} 2$ & LSO3 & & Lin & Quad & Control vs. LSO \\
\hline & $-\xi$ & $00 \mathrm{~g}$ of & tty acid & - & & & $-P$ & alue \\
\hline C4:0 & 1.72 & 1.72 & 1.57 & 1.40 & 0.12 & 0.01 & 0.35 & 0.15 \\
\hline C6:0 & 1.59 & 1.53 & 1.42 & 1.22 & 0.11 & 0.01 & 0.42 & 0.05 \\
\hline C8:0 & 0.94 & 0.92 & 0.83 & 0.71 & 0.06 & 0.01 & 0.20 & 0.01 \\
\hline C10:0 & 1.69 & 1.64 & 1.51 & 1.31 & 0.09 & $<0.01$ & 0.19 & $<0.01$ \\
\hline C11:0 & 0.25 & 0.24 & 0.22 & 0.20 & 0.02 & 0.01 & 0.58 & 0.02 \\
\hline C12:0 & 1.87 & 1.75 & 1.69 & 1.51 & 0.08 & $<0.01$ & 0.41 & $<0.01$ \\
\hline C13:0 & 0.07 & 0.06 & 0.06 & 0.06 & 0.01 & 0.51 & 0.45 & 0.26 \\
\hline C14:0 & 7.91 & 7.48 & 7.38 & 6.71 & 0.27 & $<0.01$ & 0.26 & $<0.01$ \\
\hline C14:1n-5t & 0.01 & 0.01 & 0.01 & 0.02 & 0.01 & 0.01 & 0.08 & 0.20 \\
\hline $\mathrm{C} 14: 1 \mathrm{n}-5 c$ & 0.72 & 0.68 & 0.67 & 0.66 & 0.06 & 0.04 & 0.36 & 0.03 \\
\hline C15:0 & 0.99 & 0.88 & 0.92 & 0.84 & 0.02 & $<0.01$ & 0.23 & $<0.01$ \\
\hline C16:0 & 23.27 & 22.67 & 21.20 & 19.76 & 0.62 & 0.01 & 0.16 & $<0.01$ \\
\hline $\mathrm{C} 16: 1 \mathrm{n}-5 t$ & 0.17 & 0.18 & 0.21 & 0.25 & 0.01 & $<0.01$ & 0.16 & $<0.01$ \\
\hline $\mathrm{C} 16: 1 \mathrm{n}-5 c$ & 1.28 & 1.32 & 1.12 & 1.14 & 0.07 & $<0.01$ & 0.77 & 0.03 \\
\hline C17:0 & 0.64 & 0.58 & 0.55 & 0.49 & 0.01 & $<0.01$ & 0.95 & $<0.01$ \\
\hline C18:0 & 12.08 & 12.35 & 12.29 & 12.24 & 0.41 & 0.64 & 0.39 & 0.34 \\
\hline trans $\mathrm{C} 18: 1$ & 6.19 & 6.76 & 8.17 & 9.43 & 0.34 & $<0.01$ & 0.12 & $<0.01$ \\
\hline$t-6 / 8$ & 0.46 & 0.51 & 0.64 & 0.75 & 0.02 & $<0.01$ & 0.10 & $<0.01$ \\
\hline$t-9$ & 0.43 & 0.47 & 0.58 & 0.67 & 0.02 & $<0.01$ & 0.26 & $<0.01$ \\
\hline$t-10$ & 0.56 & 0.59 & 0.72 & 0.82 & 0.03 & $<0.01$ & 0.19 & $<0.01$ \\
\hline$t-11(\mathrm{VA})$ & 3.39 & 3.62 & 4.25 & 4.89 & 0.22 & $<0.01$ & 0.10 & $<0.01$ \\
\hline$t-12$ & 0.63 & 0.71 & 0.96 & 1.14 & 0.04 & $<0.01$ & 0.10 & $<0.01$ \\
\hline$t-16$ & 0.62 & 0.69 & 0.85 & 0.97 & 0.03 & $<0.01$ & 0.30 & $<0.01$ \\
\hline $\mathrm{C} 18: 1 c 9$ & 25.44 & 25.67 & 25.14 & 25.83 & 0.72 & 0.54 & 0.33 & 0.69 \\
\hline $\mathrm{C} 18: 1 c 11$ & 0.79 & 0.79 & 0.72 & 0.74 & 0.04 & 0.02 & 0.66 & 0.92 \\
\hline $\mathrm{C} 18: 1 c 12$ & 0.27 & 0.25 & 0.34 & 0.42 & 0.02 & $<0.01$ & 0.01 & $<0.01$ \\
\hline $\mathrm{C} 18: 2 c 9 t 12$ & 0.11 & 0.11 & 0.14 & 0.19 & 0.02 & 0.01 & 0.19 & 0.10 \\
\hline $\mathrm{C} 18: 2 t 9 c 12$ & 0.05 & 0.08 & 0.1 & 0.12 & 0.01 & $<0.01$ & 0.28 & $<0.01$ \\
\hline $\mathrm{C} 18: 2 t 11 c 15$ & 0.37 & 0.47 & 0.74 & 1.07 & 0.05 & $<0.01$ & $<0.01$ & $<0.01$ \\
\hline $\mathrm{C} 18: 2 c 9 c 12$ & 1.93 & 1.96 & 1.97 & 1.95 & 0.07 & 0.69 & 0.55 & 0.52 \\
\hline CLA $c 9 t 11$ & 1.12 & 1.18 & 1.39 & 1.65 & 0.05 & $<0.01$ & 0.02 & $<0.01$ \\
\hline CLA $c 9 c 11$ & 0.02 & 0.03 & 0.04 & 0.04 & 0.01 & 0.01 & 0.40 & 0.01 \\
\hline CLA $t t$ & 0.11 & 0.15 & 0.17 & 0.19 & 0.01 & $<0.01$ & 0.33 & $<0.01$ \\
\hline C18:3n-3 & 0.59 & 0.78 & 1.01 & 1.03 & 0.04 & $<0.01$ & $<0.01$ & $<0.01$ \\
\hline C18:3n-6 & 0.01 & 0.01 & 0.01 & 0.01 & 0.01 & 0.01 & 0.21 & 0.01 \\
\hline C19:0 & 0.05 & 0.05 & 0.06 & 0.05 & 0.01 & 0.78 & 0.27 & 0.48 \\
\hline C20:0 & 0.20 & 0.18 & 0.17 & 0.14 & 0.01 & $<0.01$ & 0.60 & $<0.01$ \\
\hline C23:0 & 0.02 & 0.03 & 0.03 & 0.02 & 0.01 & 0.44 & 0.34 & 0.86 \\
\hline C24:0 & 0.05 & 0.05 & 0.05 & 0.05 & 0.01 & 0.05 & 0.46 & 0.22 \\
\hline C20:1n-9 & 0.05 & 0.03 & 0.02 & 0.02 & 0.01 & 0.01 & 0.40 & 0.02 \\
\hline C20:3n-6 & 0.02 & 0.01 & 0.02 & 0.01 & 0.01 & 0.42 & 0.54 & 0.45 \\
\hline C20:4n-6 & 0.18 & 0.16 & 0.14 & 0.11 & 0.01 & $<0.01$ & 0.30 & $<0.01$ \\
\hline C20:5n-3 & 0.05 & 0.04 & 0.04 & 0.04 & 0.01 & 0.01 & 0.54 & 0.01 \\
\hline $\mathrm{C} 22: 2 \mathrm{n}-6$ & 0.02 & 0.02 & 0.02 & 0.02 & 0.01 & 0.73 & 0.94 & 0.95 \\
\hline $\mathrm{C} 22: 4 \mathrm{n}-6$ & 0.03 & 0.04 & 0.03 & 0.03 & 0.01 & 0.59 & 0.41 & 0.70 \\
\hline C22:5n-3 & 0.08 & 0.08 & 0.08 & 0.07 & 0.01 & 0.02 & 0.10 & 0.26 \\
\hline C22:6n-3, DHA ${ }^{3}$ & 0.14 & 0.19 & 0.12 & 0.11 & 0.02 & 0.08 & 0.15 & 0.92 \\
\hline Short and medium ${ }^{4}$ & 39.30 & 38.80 & 36.80 & 33.70 & 0.96 & $<0.01$ & 0.06 & $<0.01$ \\
\hline Long $^{5}$ & 50.78 & 52.11 & 53.22 & 55.99 & 0.89 & $<0.01$ & 0.25 & $<0.01$ \\
\hline Saturated $^{6}$ & 52.30 & 52.10 & 49.90 & 46.70 & 0.89 & $<0.01$ & 0.03 & $<0.01$ \\
\hline Unsaturated $^{7}$ & 38.90 & 40.20 & 41.60 & 44.30 & 0.83 & $<0.01$ & 0.07 & $<0.01$ \\
\hline$n 3^{8}$ & 0.86 & 1.09 & 1.26 & 1.25 & 0.05 & $<0.01$ & $<0.01$ & $<0.01$ \\
\hline
\end{tabular}

${ }^{1}$ Control = control with no linseed oil; LSO1 = control with $170 \mathrm{~g} / \mathrm{d}$ of linseed oil; LSO2 = control with $340 \mathrm{~g} / \mathrm{d}$ of linseed oil; LSO3 = control with $510 \mathrm{~g} / \mathrm{d}$ of linseed oil.

${ }^{2}$ Lin $=$ linear effect, Quad $=$ quadratic , and control vs. LSO = control versus linseed oil supplementation.

${ }^{3} \mathrm{DHA}=$ docosahexaenoic acid.

${ }^{4}$ Short- and medium-chain fatty acids C4:0-16:0.

${ }^{5}$ Long = sum of long-chain fatty acids from C17:0-C24:0.

${ }^{6}$ Saturated $=$ sum of saturated fatty acids from C4:0-C24:0

${ }^{7}$ Unsaturated $=$ sum of unsaturated fatty acids from C14:1-C22:6n-3.

${ }^{8}$ Sum of all n3 fatty acids C18:3n-3-C22:6n-3. 
mers derived from the ruminal metabolism of dietary unsaturated fatty acids. It is well established that postruminal infusions of cis-9, trans-12 CLA inhibit de novo milk fatty acids synthesis in dairy cows (Baumgard et al., 2002), and dietary induced MFD has been related to increased formations of this isomer in the rumen (Bauman and Griinari, 2003). In the current study, trans-10, cis-12 CLA was not detected in milk fat. Trans-10 C18:1 has been also reported to be associated with MFD (Piperova et al., 2004; Shingfield et al., 2006). Although milk trans-10 18:1 concentration linearly increased with LSO supplementations, the concentration was still lower than those reported by Homes and AbuGhazaleh (2007; $4.1 \mathrm{~g} / 100 \mathrm{~g}$ of total fatty acids), Loor et al. (2004, $2.84 \mathrm{~g} / 100 \mathrm{~g}$ of total fatty acids), and Shingfield et al. (2006; $7.72 \mathrm{~g} / 100 \mathrm{~g}$ of total fatty acids) where MFD was reported.

As expected, milk trans C18:1 concentrations, VA in particular, increased with LSO supplementation. Supplementing dairy cow diets with plant oils increased milk trans C18:1 content under confinement (Whitlock et al., 2002; Shingfield et al., 2006; Bu et al., 2007) and grazing (Boken et al., 2005; Rego et al., 2005b; AbuGhazaleh and Holmes, 2007) feeding systems. Milk VA content averaged $3.23 \%$ (Loor et al., 2005) and $3.04 \%$ (Bu et al., 2007) of milk total fatty acids when dairy cows were fed LSO at 588 and $636 \mathrm{~g} / \mathrm{d}$, respectively. The higher milk VA concentration seen in this study with LSO diets compared with the previous 2 studies may have resulted from grazing, algae supplementation, or both. Cows on pasture-based diets have been shown to have higher levels of VA in their milk than those on conserved forages (Boken et al., 2005; Couvreur et al., 2006). Recently, Couvreur et al. (2006) reported a linear relationship between the proportion of fresh grass in dairy cow diets and milk VA. AbuGhazaleh and Jenkins (2004b) showed that DHA promotes VA accumulations in rumen by inhibiting the reduction of VA to stearic acid. In the current study, milk stearic acid concentration did not increase with LSO supplementation as seen with $\mathrm{Bu}$ et al. (2007) and Loor et al. (2005) when LSO was fed to dairy cows supporting the DHA effect on VA accumulation.

The concentration of trans-10 C18:1 in milk fat in this study was relatively low compared with that seen by Rego et al. (2005b) and Shingfield et al. (2006). Fresh forage intake may explain, in part, the lower concentration of milk trans-10 C18:1 in this study. Milk concentrations of VA increased and trans-10 C18:1 decreased in a linear manner as the proportion of fresh grass in the diet of dairy cows increased (Couvreur et al., 2006). Kay et al. (2005) reported that trans-10 C18:1 contributed $<1 \%$ of the milk total trans $\mathrm{C} 18: 1$ isomers in pasture fed cows compared with about $23 \%$ in TMR fed cows. Results from previous studies suggest that the interaction of high-dietary starch and oils leads to the largest increases in trans-10 C18:1 concentration as a result of trans-10 C18:1 replacing VA as the predominant trans C18:1 isomer (Shingfield et al., 2005; AbuGhazaleh and Jacobson, 2007a). Oil source may also explain the low milk trans-10 C18:1 concentration in this study. AbuGhazaleh and Jacobson (2007b) showed that linolenic acid was less efficient than linoleic acid (the primary fatty acid in soybean oil) in promoting trans-10 C18:1 formation.

Supplementing dairy cow diets with linolenic acid oil source increased milk cis-9, trans-11 CLA content under confinement (Dhiman et al., 2000; Loor et al., 2005; Bu et al., 2007) and grazing (Brown et al., 2006; Holmes and AbuGhazaleh, 2007) feeding systems. The linear increase in milk VA concentration with LSO and the subsequent conversion of VA to cis-9, trans-11 CLA by $\Delta^{9}$-desaturase in mammary gland may explain the linear increase in milk cis-9, trans-11 CLA content. As mentioned earlier, cis-9, trans-11 CLA in milk originates from ruminal biohydrogenation of linoleic acid as an intermediate product or from endogenous synthesis in mammary gland from VA (Griinari and Bauman, 1999). The endogenous synthesis of $c i s-9$, trans-11 CLA from VA has been proposed as the major pathway of cis-9, trans-11 CLA synthesis in lactating cows, accounting for an estimated $80 \%$ of the cis-9, trans- 11 CLA in milk fat (Mosley et al., 2006).

The increases in milk linolenic acid and DHA contents with the LSO treatments were relatively small compared with their intake (Table 2). Similar low increases in n-3 fatty acids were reported by others (Loor et al., 2005; Rego et al., 2005a; Bu et al., 2007) when n-3 lipid supplements were used. This low transfer of n-3 fatty acids from feed to milk fat may be explained by extensive ruminal biohydrogenation of linolenic acid (Harfoot and Hazlewood, 1997) and DHA (AbuGhazaleh and Jenkins, 2004a) or by their partitioning toward other tissues within the body. Kitessa et al. (2001) reported that $\mathrm{n}-3$ fatty acids are almost totally confined to plasma cholesterol ester and phospholipids, which are poorly taken up by the mammary gland (Offer et al., 1999).

\section{CONCLUSIONS}

Supplementing grazing dairy cow diets with algae and LSO increased milk cis-9, trans-11 CLA content without affecting cow's milk yield. Linseed oil supplementation caused a quadratic increase in milk fat and protein contents. The increase in milk cis-9, trans-11 CLA content was proportional to the amounts of LSO in grazing dairy cow diets. Supplementing grazing 
dairy cow diets with algae and LSO at up to $510 \mathrm{~g} /$ $d$ can improve the nutritional value of milk without compromising milk composition or cow performance.

\section{ACKNOWLEDGMENTS}

We thank the employees of the South Illinois University Dairy Research Facility for care of the cows and assistance in obtaining research data and Prairie Farms, Carterville, IL, for milk analysis. We also thank Bruce Jacobson (SIUC, Carbondale, IL) for his help in milk fatty acids analysis. This project was funded in part by the Illinois Council on Food and Agricultural Research.

\section{REFERENCES}

AbuGhazaleh, A. A., and L. D. Holmes. 2007. Diet supplementation with fish oil and sunflower oil to increase conjugated linoleic acid levels in milk fat of partially grazing dairy cows. J. Dairy Sci. 90:2897-2904.

AbuGhazaleh, A. A., and B. N. Jacobson. 2007a. Production of transC18:1 and conjugated linoleic acid production by ruminal microbes in continuous culture fermenters fed diets containing fish oil and sun flower oil with decreasing levels of forage. Animal 1:660-665.

AbuGhazaleh, A. A., and B. N. Jacobson. 2007b. The effect of $\mathrm{pH}$ and polyunsaturated C18 fatty acid source on the production of vaccenic acid and conjugated linoleic acids in ruminal cultures incubated with docosahexaenoic acid. Anim. Feed Sci. Technol. 136:11-22.

AbuGhazaleh, A. A., and T. C. Jenkins. 2004a. Disappearance of docosahexaenoic and eicosapentaenoic acids from cultures of mixed ruminal microorganisms. J. Dairy Sci. 87:645-651.

AbuGhazaleh, A. A., and T. C. Jenkins. 2004b. Short Communication: Docosahexaenoic acid promotes vaccenic acid accumulation in mixed ruminal cultures when incubated with linoleic acid. J. Dairy Sci. 87:1047-1050.

AbuGhazaleh, A. A., D. J. Schingoethe, A. R. Hippen, and K. F. Kalscheur. 2002. Feeding fish meal and extruded soybeans enhances the conjugated linoleic acid content of milk. J. Dairy Sci. 85:624-631.

AbuGhazaleh, A. A., D. J. Schingoethe, A. R. Hippen, and K. F. Kalscheur. 2003. Milk conjugated linoleic acid response to fish oil supplementation diets differing in fatty acid profiles. J. Dairy Sci. 86:944-953.

Association of Official Analytical Chemists. 2000. Official Methods of Analysis. 17th. AOAC Int., Gaithersburg, MD.

Bargo, F., J. E. Delahoy, G. F. Schroeder, L. H. Baumgard, and L. D. Muller. 2006. Supplementing total mixed rations with pasture increase the content of conjugated linoleic acid in milk. Anim. Feed Sci. Technol. 131:226-240.

Bauman, D. E., and J. M. Griinari. 2003. Nutritional regulation of milk fat synthesis. Annu. Rev. Nutr. 23:203-227.

Baumgard, L. H., W. J. Weber, G. W. Kazmer, S. A. Zinn, L. B. Hansen, H. Chester-Jones, and B. A. Crooker. 2002. Trans-10, cis-12 conjugated linoleic acids decreases lipogenic rates and expression of genes involved in milk lipid synthesis in dairy cows. J. Dairy Sci. 85:2155-2163.

Bhattacharya, A., J. Banu, M. Rahman, J. Causey, and G. Fernandes. 2006. Biological effects of conjugated linoleic acids in health and disease. (Review.). J. Nutr. Biochem. 17:789-810.

Boken, S. L., C. R. Staples, L. E. Sollenberger, T. C. Jenkins, and W. W. Thatcher. 2005. Effect of grazing and fat supplementation on production and reproduction of Holstein cows. J. Dairy Sci. 88:4258-4272.
Brown, W., A. A. AbuGhazaleh, and S. Ibrahim. 2006. Conjugated linoleic acid and omega-3 fatty acids in milk of grazing dairy cows fed fish oil and linseed oil. J. Dairy Sci. (Suppl. 1)89. (Abstr.)

Bu, D. P., J. Q. Wang, T. R. Dhiman, and S. J. Liu. 2007. Effectiveness of oils rich in linoleic and linolenic acids to enhance conjugated linoleic acid in milk from dairy cows. J. Dairy Sci. 90:998-1007.

Chilliard, Y., A. Ferlay, and M. Doreau. 2001. Effect of different types of forages, animal fat or marine oils in cow's diet on milk fat secretion and composition, especially conjugated linoleic acids (CLA) and polyunsaturated fatty acids. Livest. Prod. Sci. 70:31-48.

Couvreur, S., C. Hurtaud, C. Lopez, L. Delaby, and J. L. Peyraud. 2006. The linear relationship between the proportion of fresh grass in the cow diet, milk fatty acid composition, and butter properties. J. Dairy Sci. 89:1956-1969.

Dhiman, T. R., L. D. Satter, M. W. Pariza, M. P. Galli, K. Albright, and M. X. Tolosa. 2000. Conjugated linoleic acid content of milk from cows offered diets rich in linoleic and linolenic acid. J. Dairy Sci. 83:1016-1027.

Donovan, D. C., D. J. Schingoethe, R. J. Baer, J. Ryali, A. R. Hippen, and S. T. Franklin. 2000. Influence of dietary fish oil on conjugated linoleic acid and other fatty acids in milk from lactating dairy cows. J. Dairy Sci. 83:1-9.

Franklin, S. T., K. R. Martin, R. J. Baer, and D. J. Schingoethe. 1999. Dietary marine algae (Schizochytrium sp.) increase concentrations of conjugated linoleic acid, conjugated linoleic acid, docosahexanoic acid, and transvaccenic acid of milk in dairy cow. J. Nutr. 129:2048-2052.

Griinari, J. M., and D. E. Bauman. 1999. Biosynthesis of conjugated linoleic acid and its incorporation into meat and milk in ruminants. Pages 180-200 in Advances in Conjugated Linoleic Acid Research. M. P. Yurawecz, M. M. Mossoba, J. K. G. Kramer, M. W. Pariza, and G. J. Nelson, ed. AOCS Press, Champaign, IL.

Harfoot, C. G., and G. P. Hazlewood. 1997. Lipid metabolism in the rumen. Pages 382-426 in The Rumen Microbial Ecosystem. P. N. Hobson and C. S. Stewart, ed. Chapman \& Hall, London, UK.

Holmes, L. D. and A. A. AbuGhazaleh. 2007. Milk cis-9, trans-11 CLA and omega-3 fatty acids response to linseed oil and fish oil supplementation when dairy cows managed under confinement or grazing system. J. Dairy Sci. (Suppl. 1)90. (Abstr.)

Jenkins, T. C. 1994. Regulation of lipid metabolism in the rumen. J. Nutr. 124:1372S-1376S.

Kay, J. K., J. R. Roche, E. S. Kolver, N. A. Thomson, and L. H. Baumgard. 2005. A comparison between feeding systems (pasture and TMR) and the effect of vitamin E supplementation on plasma and milk fatty acid profiles in dairy cows. J. Dairy Res. 72:322-332.

Kitessa, S. M., S. K. Gulati, J. R. Ashes, E. Fleck, T. W. Scott, and P. D. Nichols. 2001. Utilisation of fish oil in ruminants II. Transfer of fish oil into goats' milk. Anim. Feed Sci. Technol. 89:201-208.

Kramer, J. K. G., V. Fellner, M. E. R. Dugan, F. D. Sauer, M. M. Mossoba, and M. P. Yurawecz. 1997. Evaluating acid and base catalysts in the methylation of milk and rumen fatty acids with special emphasis on conjugated dienes and total trans fatty acids. Lipids 32:1219-1228.

Loor, J. J., A. Ferlay, A. Ollier, M. Doreau, and Y. Chilliard. 2005. Relationship among trans and conjugated fatty acids and bovine milk fat yield due to dietary concentrate and linseed oil. J. Dairy Sci. 88:726-740.

Loor, J. J., F. D. Soriano, X. Lin, J. H. Herbein, and C. E. Polan. 2003. Grazing allowance after the morning or afternoon milking for lactating cows fed a total mixed ration (TMR) enhances trans11-18: 1 and cis9,trans11-18:2 (rumenic acid) in milk fat to different extents. Anim. Feed Sci. Technol. 109:105-119.

Loor, J. J., K. Ueda, A. Ferlay, Y. Chilliard, and M. Doreau. 2004. Biohydrogenation, duodenal flow, and intestinal digestibility of trans fatty acids and conjugated linoleic acids in response to dietary forage:concentrate ratio and linseed oil in dairy cows. J. Dairy Sci. 87:2472-2485.

Mosley, E. E., B. Shafii, P. J. Moate, and M. A. McGuire. 2006. Cis9, trans-11 conjugated linoleic acid is synthesized directly from vaccenic acid in lactating dairy cattle. J. Nutr. 136:570-575. 
Offer, N. W., M. Marsden, J. Dixon, B. K. Speake, and F. E. Thacker. 1999. Effects of dietary fat supplements on levels of n-3 polyunsaturated fatty acids and conjugated linoleic acids in bovine milk. Anim. Sci. 69:613-625.

Piperova, L. S., U. Moallem, B. B. Teter, J. Sampugna, M. P. Yurawecz, K. M. Morehouse, D. Luchini, and R. A. Erdman. 2004. Changes in milk fat in response to dietary supplementation with calcium salts of trans-18:1 or conjugated linoleic fatty acids in lactating dairy cows. J. Dairy Sci. 87:3836-3844.

Rego, O. A., H. J. D. Rosa, P. V. Portugal, R. Cordeiro, A. E. S. Borba, C. M. Vauzela, and R. J. B. Bessa. 2005a. Influence of dietary fish oil on conjugated linoleic acid, omega-3 and other fatty acids in milk fat from grazing dairy cows. Livest. Prod. Sci. 95:27-33.

Rego, O. A., H. J. D. Rosa, P. Portugal, T. Franco, C. M. Vouzela, A. E. S. Borba, and R. J. B. Bessa. 2005b. The effects of supplementation with sunflower and soybean oils on the fatty acid profile of milk fat from grazing dairy cows. Anim. Res. 54:17-24.

Robertson, J. B., and P. J. Van Soest. 1981. The detergent system of analysis and its application to human foods. Pages 123-129 in The Analysis of Dietary Fiber. W. P. T. James and O. Theander, ed. Marcel Dekker, New York, NY.
Schroeder, G. F., J. E. Delahoy, I. Vidaurreta, F. Bargo, G. A. Gagliostro, and L. D. Muller. 2003. Milk fatty acid composition of cows fed a total mixed ration or pasture plus concentrates replacing corn with fat. J. Dairy Sci. 86:3237-3248.

Shingfield, K. J., C. K. Reynolds, G. Hervás, J. M. Griinari, A. S. Grandison, and D. E. Beever. 2006. Examination of the persistency of milk fatty acid composition responses to fish oil and sunflower oil in the diet of dairy cows. J. Dairy Sci. 89:714-732.

Shingfield, K. J., C. K. Reynolds, B. Lupoli, V. Toivonen, M. P. Yurawecz, P. Delmonte, J. M. Griinari, A. S. Grandison, and D. E. Beever. 2005. Effect of forage type and proportion of concentrate in the diet on milk fatty acid composition in cows given sunflower oil and fish oil. Anim. Sci. 80:225-238.

Van Soest, P. J., J. B. Robertson, and B. A. Lewis. 1991. Methods for dietary fiber, neutral detergent fiber, and nonstarch polysaccharides in relation to animal nutrition. J. Dairy Sci. 74:35833597.

Whitlock, L. A., D. J. Schingoethe, A. R. Hippen, K. F. Kalscheur, R. J. Baer, N. Ramaswamy, and K. M. Kasperson. 2002. Fish oil and extruded soybeans fed in combination increase conjugated linoleic acids in milk of dairy cows more than when fed separately. J. Dairy Sci. 85:234-243. 